\title{
Kebahasaan Wujud Respon Positif Anggota Grup Whatsapp Fashion Online
}

\author{
Ocfitasari Aditian', Agus Budi Wahyudi \\ ${ }^{1,2}$ Universitas Muhammadiyah Surakarta \\ Email: ${ }^{1}$ a310170153@student.ums.ac.id, ${ }^{2}$ Abw186@ums.ac.id

\begin{tabular}{ccc}
\hline Diterima & Direvisi & Disetujui \\
$02-09-2021$ & $29-09-2021$ & $29-09-2021$ \\
\hline
\end{tabular}

\begin{abstract}
The article aims to identify the linguistic form of a positive response from members of the online fashion WhatsApp group. The research method used is descriptive qualitative. The data is in the form of expressions containing 10 positive responses. The data comes from the expression of members of the online WhatsApp fashion group "Dasterinn". The object of research is language form. Data collection techniques are observation (interview) and documentation (note). The validity technique used is triangulation. The triangulation theory chosen is the theory of interpersonal communication of symbolic interaction according to Herbert Blumer (1969) namely (1) the existence of actions based on the meaning given, (2) meaning in the interaction, and (3) meaning through the interaction process. The results of the study prove that the linguistic form of a positive response from the members of the online WA fashion group is conveyed through the characteristics of the lingual marker unit and has a relationship with the approval response which is divided into two meanings, namely the explicit meaning ('mau' and 'mau' + 'tambah') and the implied meaning ('mau' +'keep', 'ambil', and 'pesan').
\end{abstract}

Keywords: language; positive response; WhatsApp groups

Abstrak : Artikel bertujuan untuk mengidentifikasi kebahasaan wujud respon positif anggota grup WhatsApp fashion online. Metode penelitian yang digunakan adalah deskriptif kualitatif. Data berupa ungkapan yang mengandung respon positif sebanyak 10 tanggapan. Data tersebut bersumber dari ungkapan anggota grup WhatsApp fashion online "Dasterinn”. Objek penelitian berupa wujud bahasa. Teknik pengumpulan data yakni observasi (wawancara) dan dokumentasi (catat). Teknik validitas yang digunakan ialah triangulasi. Triangulasi teori yang dipilih yaitu teori komunikasi antarpribadi interaksi simbolik menurut Herbert Blumer (1969) yaitu (1) adanya tindakan berdasarkan makna yang diberikan, (2) makna dalam interaksi, dan (3) makna melalui proses interaksi. Hasil penelitian membuktikan bahwa kebahasaan wujud respon positif anggota grup WhatsApp fashion online disampaikan melalui ciri satuan penanda lingual yang di dalamnya terdapat modalitas intensional, kata ganti, kata kerja, dan leksikal serta, memiliki hubungan dengan tanggapan persetujuan yang dibagi menjadi dua makna yaitu makna tersurat ('mau' dan 'mau' + 'tambah') dan makna tersirat ('mau' + 'keep', 'ambil', dan 'pesan').

Kata kunci: bahasa; respon positif; grup WhatsApp.।

\section{PENDAHULUAN}

Masa pandemi covid-19 membuat masyarakat kesulitan, baik secara sosial maupun ekonomi. Virus korona masuk ke Indonesia pada bulan Desember 2019. Salah satu cara yang efektif yang dilakukan untuk krisis ekonomi pada masa ini dengan memanfaatkan media sosial sebagai saranan pekerjaan. Media sosial dapat dimanfaatkan sebagai alternatif dalam berbisnis yang dilakukan secara online. ${ }^{1}$ Media sosial merupakan bentuk dari perkembangan internet (Menurut Afriluyanto dalam Yusanda 2021 : 41).

Wahyudi dalam Sindang, (2013:1) menambahkan bahwa media sosial ialah aplikasi berbasis internet yang memungkinkan setiap penggunanya dapat saling berbagi konten sesuai fitur pendukungnya. Penggunaan sebuah media online dipercayai bisa memudahkan pengguna dalam berbagi jejaring sosial. Aplikasi yang dijadikan sebagai media promosi dalam berbisnis meliputi Facebook, Twitter, Instragram, Shopee, dan WhatsApp (WA).

Pemakaian media online yang memudahkan pengguna dalam bertransaksi selalu memiliki keterkaitan dengan aplikasi WhatsApp. Penggunaan aplikasi ini dipercaya mudah untuk sarana komunikasi yang dilakukan penjual kepada calon pembeli atau anggota. Wa merupakan aplikasi berbasis internet yang memudahkan penggunanya 
dalam berkomunikasi sesuai fitur. Pengiriman pesan melalui grup menjadi salah satu cara berbisnis yang mudah untuk diterapkan. Pembuatan grup dirasa dapat memudahkan proses komunikasi antar individu sebagai bukti pencapaian tujuan bersama yang dilakukan oleh penjual dengan anggota. Salah satu jenis produk yang sering kita jumpai pada proses jual beli, berhubungan dengan busana.

Polhemus dan Procter dalam (Hendariningrum, 2008) menunjukan bahwa istilah fashion sering digunakan sebagai simbol dari istilah dandanan gaya dan busana masyarakat kontemporer Barat. Busana yang sedang tren atau berkembang pesat dalam produksi dan penjualan dapat menumbuhkan rasa keinginan masyarakat untuk memilikinya seperti sepatu, topi, baju, daster, busana muslim, hijab, jaket, rok, dan kemeja. Fashion daster menjadi salah satu busana yang dicari berdasarkan kualitas bahan, jenis, motif, dan harga.

Grup WatsApp yaitu sebuah ruang kelas virtual yang memiliki fasilitas untuk setiap anggotanya dapat berkomunikasi lebih dari satu orang. Dengan Group WhatsApp, anggota satu dapat membagikan pesan, foto, dokumen dan video dengan anggota lainnya. Grup WhatsApp penelitian ini bernama "Dasterinn" yang merupakan ikon toko yang menjual daster yang terjamin kualitasnya, online shop ini dibuat pada tahun 2019 berpusat di Sragen dan Wonogiri. Variasi tipe daster yang dijual yakni yukensi (tidak berlengan), busui (daster untuk ibu menyusui), tali, setelan (rempel, kancing, dan celana) serta daster anak.

Masing-masing produk memiliki kualitas bahan berbeda seperti berbahan katun yang halus, santung yang lembut, wolfs yang halus dan chiffon yang halus dan tipis. Daster ini dijual dengan harga mulai dari 24 ribu hingga 58 ribu per potong. Berdasarkan kesuksesan yang diraih penjual melalui menjual daster memberikan wujud tanggapan baik negatif dan positif.

Menurut Simamora (2003:201) Respon ialah tingkat perubahan respon sebagai dampak stimulis. Respon positif yaitu tanggapan yang diterima penjual dari anggota dapat dimengerti dan saling pengertian sehingga anggota mendukung, menyepakati, mengiyakan, menyetujui pesan ajakan seperti termuat dalam pesan yang diterima. Penyampaian respon anggota dilalui dengan proses komunikasi. Menurut Nurudin (dalam Panuju, 2018: 62) komunikasi antarpribadi bisa terjadi antar dua orang atau diadik dan bisa juga dalam kelompok kecil. Komunikasi antarpribadi bertujuan untuk kepentingan bisnis (Dasterinn) yaitu kesepakatan antara pelaku (penjual dengan anggota grup) sangat penting.
Karya Herbert Blumer (1969) dalam WestTurner (2008: 99) ada tiga asumsi yaitu, (1) Manusia bertindak terhadap manusia lainnya berdasarkan makna yang diberikan manusia lain kepada mereka. Artinya prilaku yang dilakuan anggota secara sadar dilihat melalui respon terhadap ransangan yang diberikan penjual dengan simbol yang menggambarkan kesepakatan bersama. (2) Makna diciptakan dalam interaksi antarmanusia, maksudnya dapat digambarkan dengan tiga cara yaitu (a) mengenali makna melalui benda atau produk (daster, setelan rempel, setelan kancing, daster selutut, dan daster anak) yang dijual (b) makna dilihat kepada seseorang yang bagi siapa benda itu bermakna, dan (c) makna berasal dari sesuatu yang terjadi diantara orang lain dengan kata lain merupakan respon dari interaksi yang telah dilakukan dan (3) Makna dimodifikasi melalui proses interpretif artinya penjual menentukan benda atau produk yang mempunyai makna dan melibatkan anggota grup untuk memilih makna di dalam konteks ( melalui respon ).

Semiotika adalah nama cabang ilmu yang berurusan dengan makna. Makna tersebut dibagi menjadi dua yaitu makna tersirat dan tersurat. ${ }^{7}$ Isi tersirat ialah makna tersembunyi yang tidak diketahui secara langsung (Mascita and Rosmayati 2018) dan tersurat yakni makna yang dapat secara langsung diketahui. Maka dari itu penulis ingin mengetahui bagaimana wujud respon positif anggota grup WhatsApp fashion online, dengan pemecahan masalah menganalisis ungkapan berdasarkan maknanya. Adapun tujuan penelitian ini untuk mendeskripsikan wujud respon positif anggota grup WhatsApp fashion online.

Penelitian Prihantoro dan Fitriana (2015) ditemukan adanya penggunaan kalimat positif dan kalimat negatif yang di dalamnya terdapat modalitas intensional, epistemik, deontik, dinamik, dan aletis (kata yang ditemukan adalah ingin, mau, mungkin, pasti, izin, boleh, bisa, dapat, mampu, dan harus). ${ }^{9}$ Modalitas intensional ialah menyatakan 'keinginan', 'harapan', 'ajakan', 'pembiaran', dan 'permintaan' (Alwi, 1992:36). Makna 'keinginan' dinyatakan dengan unsur leksikal, seperti: ingin, menginginkan, mengingini, berkeinginan, menghendaki, berhasrat, mendambakan, mau, hendak, akan. Perbedaan dengan penelitian ini yakni Prihantoro dan Fitriana (1) menemukan kalimat positif dan negatif, (2) terdapat modalitas intensional, epistemik, deontik, dinamik, dan aletis. Sedangkan penelitian ini meneliti (1) ungkapan positif, dan (2) hanya terdapat satu modalitas yaitu intensional.

Hasil penelitian Syamsidah dan Raja (2014) yaitu (1) makna tersirat dalam periklanan disampaikan tepat dan sampai kepada pengguna merupakan satu langkah kreatif pihak pengiklan 
untuk usaha menarik perhatian, (2) makna tersurat dilakukan untuk memainkan peranan yang penting dalam pengiklanan. Hasil penelitian ini (1) makna tersirat dalam respon grup WhatsApp fashion Online disampaikan kepada penjual melalui ciri wujud dan Fashion berupa tanggapan persetujuan, penolakan, kritik, pujian. (2) makna tersurat disampaikan anggota kepada penjual melalui ciri wujud dan fashion berupa tanggapan persetujuan, kritik, pujian. Persamaannya sama-sama membahas makna tersirat dan tersurat. Perbedaan dengan penelitian ini yaitu Syamsidah dan Raja membahas periklanan sedangkan penelitian ini tentang respon positif anggota grup WhatsApp fashion online.

\section{METODE PENELITIAN}

Penelitian ini menggunakan jenis penelitian deskriptif kualitatif, artinya data berupa tulis. Fenomena yang dimaksud adalah Kebahasaan respon positif anggota WhatsApp grup fashion online. Data berupa ungkapan yang mengandung respon positif sebanyak 15 tanggapan. Data tersebut bersumber dari ungkapan anggota grup WhatsApp fashion online "Dasterinn". Objek penelitian berupa bahasa wujud respon anggota WhatsApp grup “Dasterinn”.

Teknik pengumpulan data menggunakan teknik Observasi (wawancara) dan Dokumentasi (catat). Teknik validitas yang digunakan penelitian ini adalah teknik triangulasi. Triangulasi teori adalah rumusan informasi yang dibandingkan dengan teori yang dipilih yaitu teori komunikasi antarpribadi interaksi simbolik menurut Herbert Blumer (1969) yaitu (1) adanya tindakan berdasarkan makna yang diberikan, artinya perilaku yang dilakukan anggota secara sadar dilihat melalui respon terhadap rangsangan yang diberikan penjual dengan simbol yang menggambarkan kesepakatan bersama. (2) makna dalam interaksi, maksudnya makna dapat digambarkan melalui tiga cara yaitu a) mengenali makna melalui benda atau produk (daster, setelan rempel, setelan kancing, daster selutut, dan daster anak) yang dijual, b) makna dilihat kepada seseorang yang bagi siapa benda itu bermakna, dan c) makna berasal dari sesuatu yang terjadi diantara orang lain dengan kata lain merupakan respon dari interaksi yang telah dilakukan. dan (3) makna melalui proses interaksi, artinya penjual menentukan benda atau produk yang mengndung makna dan melibatkan anggota grup serta melakukan transformasi makna didalam konteks melalui respon. Jika dirasa data sudah dapat menghasilkan kesimpulan maka data tersebut menghasilkan kebenaran pada penelitian ini yaitu memiliki ketetapan.

\section{HASIL DAN PEMBAHASAN}

Data ungkapan yang dianalisis berjumlah 10 respon anggota Dari wujud respon positif yang dihasilkan dibedakan menjadi dua, yaitu (a) Wujud respon positif anggota WA grup fashion online makna Tu (tersurat) dan (b) Wujud respon positif anggota WA grup fashion online makna $\mathrm{Ti}$ (tersirat). Wujud respon positif masing-masing terdapat ciri satuan pembeda lingual seperti kata "mau", "mau +tambah", "mau+ keep", "ambil", dan "pesan" yang juga memiliki jenis kata berbeda yakni modalitas intensional, modalitas intnsional dan kata kerja, kata ganti, dan leksikal ( kata yang mengacu pada benda) Berikut ini hasil analisis dan pembahasanya.

\section{HASIL ANALISIS}

\section{A. Wujud Respon Positif Anggota WA Grup Fashion Online}

Ada ungkapan berwujud respon positif sebanyak 10 respon. Cirinya terdapat satuan lingual penanda respon, yaitu kata "mau", "mau tambah", "mau keep", "ambil", dan "pesan" sebagai pengisi predikat $(\mathrm{P})$. Perhatikan tabel berikut.

\section{Tabel 1. Wujud Respon Positif Anggota WA Grup Fashion Online}

\begin{tabular}{|c|c|c|}
\hline No & Data ungkapan & $\begin{array}{c}\text { Ciri penanda } \\
\text { satuan lingual }\end{array}$ \\
\hline 1 & $\begin{array}{l}\text { Kak, aku mau daster } \\
\text { tali yang warna putih } \\
\text { ini } 2 \text { pcs. }\end{array}$ & $\mathrm{Mau}$ \\
\hline 2 & $\begin{array}{l}\text { Aku mau daster busui } \\
\text { yang pink } 1 \mathrm{kak}\end{array}$ & Mau \\
\hline 3 & 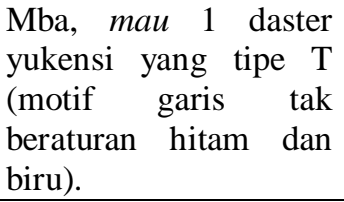 & Mau \\
\hline 4 & $\begin{array}{l}\text { Aku mau tambah } \\
\text { setelan baju anak motif } \\
\text { bunga } 1 \text { pcs kak }\end{array}$ & $\mathrm{Mau}+$ tambah \\
\hline 5 & $\begin{array}{l}\text { Kak, aku mau tambah } \\
\text { setelan celana panjang } \\
\text { hijau 1pcs. }\end{array}$ & $\mathrm{Mau}+$ tambah \\
\hline 6 & $\begin{array}{l}\text { Kak, aku mau keep } \\
\text { yang motif matahari }\end{array}$ & Mau + keep \\
\hline 7 & $\begin{array}{l}\text { Oke, aku ambil } 1 \text { yang } \\
\text { ini! (daster busui motif } \\
\text { batik corak hitam-biru) }\end{array}$ & Ambil \\
\hline 8 & $\begin{array}{l}\text { Iya kak, aku ambil } 1 \\
\text { yang No. } 2 \text { (daster } \\
\text { busui batik merah). }\end{array}$ & Ambil \\
\hline 9 & $\begin{array}{l}\text { Aku pesan 1 kodi } \\
\text { daster random kak. }\end{array}$ & Pesan \\
\hline
\end{tabular}


\begin{tabular}{|l|l|l}
\hline 10 & Kak pesan daster busui & Pesan
\end{tabular} coklat 3 pcs.

Tabel 1. Wujud respon positif anggota pada 10 ungkapan ini menghasilkan dua jenis makna, yaitu makna tersurat dan tersirat yang merupana wujud respon positif ungkapan persetujuan anggota dengan penjual. Kedua makna ini akan dibahas melalui sub bab (a) Wujud respon positif anggota WA grup fashion online makna Tu (tersurat) dan (b) Wujud respon positif anggota WA grup fashion online makna Ti (tersirat) sebagai berikut.

\section{Wujud Respon Positif Anggota WA Grup Fashion Online Makna Tu}

Ada ungkapan berwujud respon positif sebanyak 10 respon. Cirinya terdapat satuan lingual penanda respon, yaitu kata "mau" sebagai pengisi predikat $(\mathrm{P})$ yang sebenarnya bentuk kata mau itu sama dengan modalitas intensional (kemauan). Perhatikan data berikut.

\section{Kata Mau}

Ciri penanda:

$\mathrm{S}+\frac{\mathrm{P}}{\mathrm{Mau}}+\mathrm{Pel} / \mathrm{O} / \mathrm{K}$

Contoh:
1) Dini
: Kak, aku mau daster tali yang
2) Ratu warna putih ini 2 pcs (Data 1)
:Aku mau daster busui yang pink 1 kak (Data 2)
3) Ratu

\begin{abstract}
: Mba, mau 1 daster yukensi yang tipe $\mathrm{T}$ (motif garis tak beraturan hitam dan biru). (Data 3)
\end{abstract}

\section{a. Analisis data 1- 3}

Data (1) “... daster tali yang warna putih 2pcs", merupakan setuju berdasarkan tipe dan warna, buktinya kata daster tali berarti 'tipe' dan putih berarti 'warna'. Kata mau berarti anggota memiliki kemauan untuk membeli, dan kata ini termasuk modalitas intensional (kemauan). Kalimat dalam data 1 memiliki makna jelas (tersurat) positif bahwa Dini membeli daster tali putih berjumlah 2pcs kepada penjual melalui grup Whatsapp fashion Online.

Data (2) “... daster busui yang pink 1pcs", merupakan setuju berdasarkan tipe dan warna terbukti kata daster busui berarti 'tipe daster', Pink sama dengan 'warna'. Pengertian kata busui berarti ibu menyusui maksudnya daster ini dibuat dengan ukuran yang sesuai dengan baju untuk ibu menyusui dilengkapi dengan resleting agar mudah memakainya. Kata mau berarti anggota memiliki kemauan untuk membeli, dan kata ini termasuk modalitas intensional (kemauan). Kalimat dalam data 2 memiliki makna tegas berwujud positif bahwa Ratu membeli daster model busui yang berwarna Pink berjumlah 2pcs.

Data (3) “... 1pcs daster yukensi tipe ini (corak hitam ,biru)", merupakan setuju berdasarkan tipe motif . Kata daster yukensi berarti 'tipe', dan corak hitam biru berarti 'motif'. Kata Yukensi dalam fashion ialah daster yang berjenis tanpa lengan, artinya model ini dapat dijadikan baju muslim dengan menambahkan manset untuk lengannya. Kata mau berarti anggota memiliki kemauan untuk membeli, dan kata ini termasuk modalitas intensional (kemauan). Kalimat dalam data 3 memiliki makna jelas berwujud positif, Ratu membeli lagi daster dengan model berbeda yakni yukensi bermotif corak hitam biru sebanyak 2 pcs.

\section{Kata Mau + Tambah}

Terdapat respon positif berciri penanda satuan lingual Mau + KK (Kata kerja), yaitu kata "mau tambah" dan " mau keep" sebagai pengisi predikat (P) yang sebenarnya bentuk kata mau itu sama dengan modalitas intensional (kemauan) sedangkan kata tambah sama dengan kata kerja.

Ciri penanda :

\begin{tabular}{|c|c|c|}
\hline \multirow[t]{2}{*}{$\mathrm{S}+$} & $\mathrm{P}$ & $+\mathrm{Pel} / \mathrm{O} / \mathrm{K}$ \\
\hline & Mau + tambah & \\
\hline
\end{tabular}

4) Adhinta : Aku mau tambah setelan baju anak motif bunga 1 pcs kak. (Data 4)

5) Silvia : Kak, aku mau tambah setelan celana panjang hijau 1 pcs.

(Data 5)

\section{b. Analisis data 4-5}

Data (4) “... setelan baju anak motif bunga 1pcs", merupakan setuju berdasarkan tipe dan motif, terbukti pada kata setelan baju anak berarti 'tipe', dan bunga berarti 'motif. Kata setelan baju anak dalam fashion memiliki arti 'mengenai satu potong baju dan celana yang memiliki warna atau motif selaras atau cocok dikenakan unjuk anak'. Ukuran baju ini didesain untuk anak berusia di bawah 5 tahun, sehingga sebelum membeli diwajibkan anggota harus dapat mengira-ngira kesesuaian ukuran yang diinginkan. Kata tambah 
berarti anggota yang pemesanan awal berhasil, kemudian ia ingin memesan kembali dengan menggunakan imbuhan kata kerja tambah. Kalimat dalam data 4 memiliki makna berwujud positif bahwa Adhinta menambah pesanannya dengan membeli setelan baju anak bermotif bunga dengan jumlah 1 pes atau 1 potong.

Data (5) “... setelan celana panjang hijau 1pcs", merupakan setuju berdasarkan tipe dan warna, terbukti pada kata setelan celana panjang berarti 'tipe' dan hijau berarti 'warna'. Kata setelan celana panjang dalam fashion memiliki arti 'satu potong baju beserta celana panjang yang dijual dengan harga satu barang memiliki dua produk, maksudnya baju dan celana yang di beli anggota nantinya hanya di bayar dengan satu harga yakni baju dengan celana panjang tidak di jual ecer'. Kata tambah berarti anggota yang pemesanan awal berhasil, kemudian ia ingin memesan kembali dengan menggunakan imbuhan kata kerja tambah. Kalimat dalam data 5 memiliki makna berwujud positif bahwa Silvia ingin menambahkan jumlah pesanannya dengan membeli setelan celana panjang berwarna hijau dengan jumlah 1 pcs atau 1 potong.

\section{Wujud Respon Positif Anggota WA Grup Fashion Online Makna Ti}

Ada ungkapan berwujud respon positif sebanyak 10 respon. Cirinya terdapat satuan lingual penanda respon yaitu Mau + KK (Kata kerja), yaitu kata "mau keep" sebagai pengisi predikat (P) yang sebenarnya bentuk kata mau itu sama dengan modalitas intensional (kemauan) sedangkan keep sama-sama termasuk kata kerja.

\section{Kata Mau + Keep}

Ciri penanda :

\begin{tabular}{|ccc|}
$\mathrm{S}+$ & $\mathrm{P}$ & $+\mathrm{Pel} / \mathrm{O} / \mathrm{K}$ \\
\cline { 2 - 2 } & $\mathrm{Mau}+$ Keep \\
\end{tabular}

\section{Contoh:}

6) Indah : Kak, aku mau keep yang motif
matahari.

\section{a. Analisis data 6}

Data (6) “... motif matahari 1pcs", merupakan setuju berdasarkan motif. Buktinya kata motif matahari sama dengan 'motif. Terdapat kata asing Keep dalam bahasa Indonesia berarti menyimpan, makna kata ini sebenarnya diberikan anggota kepada penjual bahwa Indah memberikan informasi untuk menyimpankan daster yang ingin ia beli. Namun dalam penyampaian kata yang tidak jelas ini dapat membuat pembaca kesulitan untuk memahami maksud ungkapan anggota. Kata mau keep berarti 'mau menyimpan', kata menyimpan memiliki arti makna tersirat. Kata $P c s$ singkatan yang berarti 'jumlah' yang menunjukkan satuan jumlah barang lebih dari satu. Kalimat ke 6 memiliki makna berwujud positif yang menyatakan Indah ingin membeli daster motif matahari berjumlah 1pcs dengan meminta penjual menyimpannya, agar tidak ada dapat membelinya selain Indah.

\section{Kata Ambil}

Terdapat respon positif berciri penanda satuan lingual yaitu kata "ambil" sebagai pengisi predikat $(\mathrm{P})$ yang sebenarnya itu sama dengan kata ganti.

Ciri Pembeda :

$\mathrm{S}+\frac{\mathrm{P}}{\mathrm{T}}+\mathrm{Pel} / \mathrm{O} / \mathrm{K}$

Contoh:

7) Anjas : Oke, aku ambil 1 yang ini! (daster busui motif batik corak hitam-biru)

(Data 7)

8) Ayuk : Iya kak, aku ambil 1 yang No. 2 (daster busui batik merah).

(Data 8)

\section{b. Analisis data $7-8$}

Data (7) “... 1 yang ini! (daster busui motif batik corak hitam-biru)", merupakan setuju berdasarkan tipe dan motif, terbukti pada kata yang ini menunjukkan 'tipe serta motif'. Kata ini disampaikan lewat gambar sehingga pembaca yang tidak mengetahui deskripsi dari daster yang di jual oleh penjual akan merasa bingung, sebaiknya setelah kalimat tersebut diberi keterangan yang cukup yakni 'daster busui motif batik corak hitambiru'. Kata ambil sama dengan kata ganti yang dapat menumbuhkan kecurigaan antara hanya berniat tanpa membeli atau sebaliknya. Kalimat dalam data 7 memiliki makna kurang jelas namun berwujud positif yaitu Anjas membeli 1pcs daster busui motif batik corak hitam-biru.

Data (8) “... 1 yang No. 2 (daster busui batik merah)", merupakan setuju berdasarkan tipe dan motif, terbukti pada kata yang No. 2 menunjukkan 'tipe serta motif', alasannya pada kata ini diperlihatkan gambar sehingga pembaca yang tidak mengetahui deskripsi dari daster yang di jual oleh penjual akan merasa bingung, sehingga sebaiknya 
setelah kalimat tersebut diberi keterangan yang cukup yakni 'daster busui batik merah'. Kata ambil sama dengan kata ganti yang dapat menumbuhkan kecurigaan antara hanya berniat tanpa membeli atau sebaliknya. Kalimat dalam data 8 memiliki makna samar-samar namun berwujud positif yaitu Ayuk membeli 1pcs daster busui motif batik warna merah.

Terdapat respon positif berciri penanda satuan lingual yaitu kata "pesan" sebagai pengisi predikat (P) yang sebenarnya itu sama dengan leksikal (mengacu pada benda).

\section{Kata Pesan}

Ciri penanda:

S $\mathrm{S}$ Pesan
Contoh:

9) Ninin : Aku pesan 1 kodi daster random kak.

(Data 9) 10)Adhinta : Kak pesan daster busui coklat
3pcs
(Data 10)

\section{c. Analisis data 9-10}

Data (9) “... 1 kodi daster random” setuju berdasarkan tipe dan motif buktinya kata random dalam bahasa Indonesia berarti mengambil secara acak sehingga kata ini dapat diartikan bahwa Ninin setuju membeli dan menerima daster yang telah ia beli. Penggunaan kata pesan sama merupakan jenis kata leksikal artinya kata yang mengacu pada benda, maksudnya penulisan kata pesan dapat dipahami oleh penjual, tetapi dalam bahasa pemaknaannya tidak jelas sulit dipahami, kalimat dalam data 9 memiliki makna kurang jelas berwujud positif yakni anggota ingin atau hanya memesan saja daster 1 kodi atau 20pcs yang diambil secara acak oleh penjual.

Data (10) “... daster busui coklat 3pcs", merupakan setuju berdasarkan tipe dan warna buktinya daster busui berarti 'tipe' dan coklat berarti 'warna'. Kata pesan merupakan jenis kata leksikal artinya kata yang mengacu pada benda, maksudnya penulisan kata pesan dapat dipahami oleh penjual, tetapi dalam bahasa pemaknaannya tidak jelas sulit dipahami, kalimat dalam data 9 memiliki makna kurang jelas atau tersirat dan wujud positifnya yakni anggota Wujud inti positif dari tanggapan ini ialah memberikan informasi bahwa Adhinta membeli daster busui warna coklat berjumlah 3 pcs.

\section{PEMBAHASAN}

Artikel ini memberikan penjelas pada wujud respon positif anggota grup WhatsApp fashion online. Penelitian ini memberikan informasi tentang kebahasaan respon positif anggota grup WhatsApp fashion online melalui makna tersirat dan tersurat.

Hasil penelitian (Fransisca 2019) menjelaskan bahwa (1) makna tersurat kata moderat adalah pertengahan, dan (2) makna tersiratnya yakni seseorang yang disetujui moderat dituntut untuk mengatasi masalah yang dihadapi. Sementara hasil penelitian ini menunjukkan (1) makna tersurat kata 'mau', dan 'mau + tambah' yang berarti anggota grup jelas memberi tanggapan positif setuju membeli daster yang ditawarkan penjual serta (2) makna tersirat kata 'mau' + 'keep', 'ambil' dan 'pesan' yakni suatu tanggapan yang memiliki makna kurang jelas namun terhubung dengan tanggapan persetujuan, sehingga perlunya penambahan keterangan untuk dapat memiliki makna positif setuju membeli daster yang diinginkan anggota grup WhatsApp fashion online. Persamaannya sama-sama membahas makna tersirat dan tersurat. Untuk perbedaan pada kata moderat antar umat islam, dengan wujud respon positif anggota grup WhatsApp melalui kata 'mau', 'mau + tambah', 'mau + keep' , 'ambil' dan 'pesan'.

\section{KESIMPULAN}

Dari pembahasan tersebut, berupa simpulan: Pertama, wujud respon positif anggota grup dapat dibedakan menjadi dua yaitu wujud bermakna tersirat dan tersurat. Kedua, makna tersurat diperlihatkan pada kata "mau" (modalitas intensional), dan "mau $+\mathrm{KK}$ " (modalitas intensional + kata kerja). Ketiga makna tersirat dilihat pada kata "ambil" (kata ganti), "pesan" (leksikal), "mau' + 'keep" (modalitas intensional + kata kerja). keempat, respon positif berciri satuan lingual pembeda pespon yakni kata 'mau', 'mau + tambah', 'mau keep', ‘ambil' dan 'pesan'.

\section{REFERENSI}

Afriluyanto, Tegar Roli. 2015. "Fenomena Remaja Menggunakan Media Sosial Membentuk Identitas". KOMUNIKA: Jurnal Dakwah dan Komunikasi, 11(2), 184-197.

Bachri, Bachtiar S. 2010. "Meyakinkan Validitas Data melalui Triangulasi Pada Penelitian Kualitatif." Jurnal Teknologi Pendidikan, 
10

(1),

46-62.

http://yusuf.staff.ub.ac.id/files/2012/11/m eyakinkan-validitas-data-melalui$\underline{\text { triangulasi-pada-penelitian-kualitatif.pdf }}$

Barkati, Haerum. 2014. "Fashion Androgini Dalam Pendekatan Fotografi Editorial Di Kota Bandung". Skripsi. Bandung: Universitas Pasundan.

Barseli, Mufadhal,. Kristinus Sembiring, Ifdi Ifdil, dan Linda Fitria. 2018. "The Concep Of Student Interpersonal Communication". JPPI (Jurnal Penelitian Pendidikan Indonesia), $\quad 4(2) \quad 129-$ 134.http://jurnal.itats.ac.id/wpcontent/uploads/2015/10/1.-ChoirulAnam_ITATS. pdf.

Feralina, Novi. 2013. "Analisis Semiotika Makna Pesan Non Verbal Dalam Iklan Class Mild Versi "Macet" di Media Televisi". eJournal Ilmu Komunikasi, 1(4), 353-365.

Fitria, Tira Nur. 2017. "Bisnis Jual Beli Online (Online Shop) dalam Hukum Islam dan Hukum Negara”. Jurnal Ilmiah Ekonomi Islam, 3(1), 52-62. https://jurnal.stieaas.ac.id/index.php/jei/article/view/99

Fransisca, Malia. 2019. "Moderat Antar Umat, Organisasi dan Pendidikan. JUSPI (Jurnal Sejarah Peradaban Islam), 3 (1), hal. 85 92.

DOI: http://dx.doi.org/10.30829/juspi.v3i1 .4375

Hapsari, Ayu Dyah., dan Mohammad Iqbal. 2018. "Analisis Pasar Fashion Wanita Berdasarkan Motif Pembelian Dan Shopping Lifestyle (Survei pada Konsumen Fashion item Wanita di Kota Surabaya dan Malang)". Jurnal Administrasi Bisnis (JAB), 64(2), 27-35.

Harahap, Hamida Syari,. dan Dessy Indah Kurniawati. 2018. "WhatsApp sebagai Media Strategi Komunikasi Ustadzah dalam Menyampaikan Dakwah (Studi Deskriptif Kualitatif Komunitas "Belajar Islam Seru")". DiMCC Conference Proceeding, 1, 131-150.

Hastary, Mayrita. 2014. “ Makna yang Tersirat dalam Bahasa Puisi "Jangan Tanggung Jangan Kepalang" Karya Sultan Takdir Alisyahbana”. Bina Bahasa, 7 (1), 17-26.

Hendariningrum, Retno,. dan M. Edy Susilo. 2008. "Fashion dan Gaya Hidup: Identitas dan
Komunikasi”. Ilmu Komunikasi, 6,(2), 2532.

Koroh, Tince. 2020. "Respon Mahasiswa Terhadap Pembelajaran Daring dan Kemandirian Belajar Mahasiswa Belajar Mahasiswa Selama Pandemi Covid-19”. Widyadewata : Jurnal Balai Diklat Keagamaan Denpasar, 3, 54-59.

Krisna, Wijayanti. 2016. "Makna Pesan Pada Film Action (Analisis Semiotik pada Film Action yang Mencapai Box Office Tahun 2015)", Semiotika, 10 (1), 207-240. Doi: http://dx.doi.org/10.30813/s:jk.v10i1.30

Mascita, Dede Endang, dan Ati Rosmayati. 2018. "Pembangunan Bahasa Ajar Teks Anekdot berbasis Kearifan Lokasi Untuk Siswa Kelas X SMA”. Jurnal Tuturan, 7 (1), hal: $803 \quad$ - $813 . \quad$ doi: http://dx.doi.org/10.33603/jt.v7i1.1698

Merdekawati, Yulia. 2017. "Penerapan Metode Permukaan Respon Untuk Optimalisasi Kulitas Produk (Studi Kasus: Pengembangan Produk Cake Dengan Subtitusi Tepung Kacang Merah)”. Skripsi. Makassar: Universitas Islam Negeri Alaudin.

Panuju, Redi. 2018. "PENGANTAR STUDI (ILMU) KOMUNIKASI Komunikasi sebagai kegiatan Komunikasi sebagai Ilmu Edisi 1". Jakarta: PRANSDSMRDIS GROUP.

Prasetiywati, Tri Heni. 2010. "Respon Masyarakat Kliwonan Terhadap Program Siaran di Statiun TV Komunitas-Grabag TV”. Skripsi. Yogyakarta: Universita Islam Negeri Sunan Kalijaga Yogyakarta.

Prihantoro, Edy. (2015). Modalitas dalam teks berita online. Prosiding Pesat (Psikologi, Ekonomi, Sastra, Arsitektur \& Teknik Sipil) Universitas Gunadarma, Vol. 6, h. 17-25.

Raharti. 2019. “"WhatsApp” Media Komunikasi Efektif Masa Kini (Studi Kasus Pada Layanan Jasa Informasi Ilmiah di Kawasan PUSPITAKA)". Visi Pustaka, 21(2), 147-156.

Rachmaniar, Renata Anisa. 2017. "Studi Deskriptif Tentang Loyalitas Peserta Grup WhatsApp". Sosioglobal : Jurnal Pemikiran dan Penelitian Sosiologi, 2(1):32-39. 
Sembada, Windhiadi Yoga,.dan Sonia Vivian. 2020. "Interaksi Simbolik dalam Proses Pewarisan Bahasa Masyarakat Nias Kepada Generasi Z. Jurnal Komunikasi Universitas Garut: Hasil Pemikiran dan Penelitian, Vol. 6, No. 2, 560-569.

Sukrillah,A., IA Ratnamulyani, dan AA Kusumadinata. 2017. "Pemanfaatan Media Sosial Melalui Whatsapp Group Fei Sebagai Sarana Komunikasi”. Jurnal Komunikatio 3(2): 95-104.

Suwandi. 2018. "Respon Anggota Terhadap Pelayanan Koperasi Smpan Pinjam”. Journal of Entepreneurship, Management, and Industry (JEMI), 1(1), 29-33.

Tyaswara, Baruna,. Reza Rizkina Taufik, Mahardiansyah Suhadi, dan Ratna Danyati. 2017. "Pemaknaan Terhadp Fashion Style Remaja di Bandung". 293-297. Jurnal Komunikasi, $\quad$ 8(3),

Wenerda, I. (2019). “Grup WhatsApp Sebagai Wadah Komunikasi Ibu-Ibu di Era Digital". Jurnal Penelitian Pers Dan
Komunikasi Pembangunan, 23(1), 4353.https://doi.org/10.46426/jp2kp.v23i1.1 $\underline{05}$

Widiyaningrum, Dewi Karunia. 2019. “Implikatur Percakapan pada Respon Verbal Tokoh Haruko dalam Drama Nihonjin no Shiranai Nihongo Karya Yoshihiro Izumi”. Japanese Research on Linguistics, Literature, and Culture, 1 (2), 198-225.

Widodo, Tri. 2013. "Respon Konsumen Terhadap Produk Makanan Instan”. Among Makarti, 6(12), 10-28.

Willy, Wiryani. 2018. “Analisis Fashion Brand Terhadap Perilaku Konsumen Wanita Pengguna Sosial Media Di Surabaya Barat". PERFORMA: JJurnal Manajemen dan Start-Up Bisnis 3 (1), 128-137.

Zoest, Aart van, 1930. "Semiotika: tentang tanda, cara kerjanya dan apa yang kita lakukan dengannya”.Terjemah, Ani Soekawati; Jakarta: Yayasan Sumber Agung. 